\title{
QUALITY CHANGE OF SALTED MUGIL CEPHALOUS (BOURI FISH) SPECIES DURING STORAGE AT AMBIENT TEMPERATURE
}

\author{
GAMILAT A. EL-SAID ${ }^{1}$, SALEH SHAFEIK ${ }^{1}$ and ABEER E. ABD-EL- GHAFAR ${ }^{2}$ \\ ${ }^{1}$ Department of Food Hygiene, Animal Health Research Institute, Mansoura Lab. \\ ${ }^{2}$ Department of Microbiology, Animal Health Research Institute, Mansoura Lab.
}

Received: 5 June 2016; $\quad$ Accepted: 22 June 2016

\begin{abstract}
The present study was performed to investigate the influence of salt (25\%) and storage time under room temperature on the sensory, nutritive value and microbiological analysis of salted Mugil Cephalous. Protein, crude fat, ash, $\mathrm{pH}$, fiber and moisture content were analyzed in fresh fish and after salting. Sensory evaluations were improved with time until 3 months, after 3 months sensory evaluations were badly affected. Chemical composition was reduced during storage period and the reduction was statistically significant $(\mathrm{p}<0.05)$ during 6 months of storage time. The average of Aerobic Plate Count (APC) at 0 week, month1, month2, month3, month4, month5 and month6 were $6.5 \times 10^{3} \pm 1.62 \times 10^{3}, 4.5 \times 10^{3} \pm 1.41 \times 10^{2}, 2 \times 10^{3} \pm 1.01 \times 10^{2}, 1.5 \times 10^{3} \pm 10^{2}$, $<100,<100$ and $<100$, respectively. While the Staphaureus counts were $2.5 \times 10^{2} \pm 1.01 \times 10^{2}, 1.5 \times 10^{2} \pm 1.13 \times 10$, $<100,<100,<100,<100$ and $<100$ respectively, the APC and Staph aureus counts were reduced during the storage time. Yeast-mold and Anaerobic counts were absent. $\mathrm{Cl}$. Botulinum cannot be isolated. The result of this study indicated that salted fish stored for 3 months had the best quality and shelf life for Mugil Cephalous Species.
\end{abstract}

Key words: Quality change, Mugil cephalous, Storage, Ambient temperature.

\section{INTRODUCTION}

Safety of fish product and their quality assurance is one of the main problems of food industry today. The presence or absence of food borne pathogens in a fish product is a function of the harvest environment, sanitary conditions, and practices associated with equipment and personnel in the processing environment (Food and Drug Administration, 2001 and Huss, 2003). The handling of fish product during process involves a risk of contamination by pathogenic bacteria such as Staph aureus causing food borne human intoxication (Shena and Sanjeev, 2007). Salting process is considered as one of the oldest methods of fish preservation, and this process is still been used in several places around the world. The effect of salt is to obstruct or destroy the growth of the microorganism, where in this way, the fish meat gets its way to durability. The preservation period of product is linked to the amount of salt added, therefore a straight proportion is present between the amount of salt used and the preservation period (Bahri et al., 2006).

Corresponding author: Dr. SALEH SHAFEIK

E-mail address: saleh-shafik@yahoo.com

Present address: Department of Food Hygiene, Animal Health Research Institute, Mansoura Lab.
Salted fish products are popular in many countries around the globe. Such product proved its safety for millenniums even in developed countries (Turan et al., 2007).

This study was to carry out the effect of salting process as well as storage temperature on sensory, chemical and microbiological analysis of the Mugil Cephalous.

\section{MATERIALS AND METHODS}

\section{A- Collection of samples:}

Samples of fresh Mugil Cephalou. fish were Collected from local fish market. In polyethylene bags with crushed ice and transported to the Mansoura lab where chemical and microbiological analysis were immediately carried out.

\section{B- Salting Process:}

The collected fishes were washed, eviscerated and thereafter for purpose of salting, a total weight of salt estimated $25 \%$ of the fish weight was used. The procedure used is called dry salting. In this method salt was applied by hand and brushed of the fish surface; the inner lining of eviscerated abdominal cavity and the gills chambers. This process was 
conducted by separating the fish layers by coarse salt mattresses inside a plastic container. The stack of the fish and salt are left about 7 days to let the salt penetrate the muscles, followed by extracting the fish fluids through plasmolysis. The extracted fluid (Pickle) was allowed to drain continuously. Used salt was removed from the fish surfaces and the fish restacked with new dry salt between the layers once during the ripening process. Salted product, was packed in polyethylene bags and stored at room temperature for six months.

\section{C- Sensory Evaluation:}

For examination purposes, end products were submitted on 20 persons test panel. Comparison was carried out in terms of organoleptic characteristics, such as color, flavor, test, texture and general appearance. The panel was requested to rate each organoleptic feature of the end products according to a 10 point scale $(10=$ excellent; $8-9$ very good; $6.5-7.9$ good; 5-6.4 fair; $<5$ bad), using the score method as reported by (Afolbi et al., 1984).

\section{D- Sample preparation (AOAC, 2000)}

Firstly the fish length and weight taken and after that the fish heads, scales, tails, fins, guts and inedible bones were removed and discarded. The fish were filleted to obtain all flesh and skin from head to tail and from top back to belly on both sides. The fillet were thoroughly homogenized in a sterile mortar and used for examination. Some parts of homogeneous selected randomly for chemical analysis and chemical indicates spoilage tests the other parts of the homogeneous subjected to proximate analysis.

\section{E- Chemical Analysis:}

The water was determined on approximately $5 \mathrm{~g}$ of minced muscle by oven drying at $105 \pm 3^{\circ} \mathrm{C}$ until a constant weight, following technique 950.46 [Association of Official Analytical Chemists (AOAC, 2000). Percent protein (Kjeldahl N X 6.25) was determined from a $1 \mathrm{~g}$ sample for each treatment by AOAC (2000). Lipid was extracted from samples with a mixture of chloroform, methanol, and water (Bligh and Dyer, 1959). Ash was determined by dryashing in a furnace at $550 \pm 5^{\circ} \mathrm{C}$ for $24 \mathrm{~h}$ (AOAC, 2000). The $\mathrm{pH}$ was measured as described by Ludorf and Meyer (1973) using a digital pH meter (Hanna Germany). Mohr method was used to determine salt content in fish muscle (AOAC, 2000)

\section{Microbiological Analysis:}

Preparation of samples:

The collected samples were prepared according to the technique recommended by (ICMSF, 1996). The prepared samples were subjected to the following examination:

- Determination of Aerobic Plate Count (APC) according to (APHA, 2001).

- Determination of Staph aureus count according to (Food and Drug Administration, 2001).

- Determination of yeast-mold count (ISO 21527, 2008).

- Enumeration of Anaerobic count according to (Pifco, 1974).

- Isolation of $\mathrm{Cl}$. botulinum according to (Eyre, 2009).

\section{RESULTS}

Table 1: Chemical composition of fresh Mugil Cephalous (g/100g)

\begin{tabular}{cc}
\hline Parameters & Average \\
\hline Moisture & $63.23 \pm 1.35$ \\
\hline Ash & $2.4 \pm 0.19$ \\
\hline Protein & $18.40 \pm 0.59$ \\
\hline Lipid & $14.63 \pm 0.34$ \\
\hline Fiber & $1.34 \pm 0.12$ \\
\hline pH & 6.6 \\
\hline
\end{tabular}


Table 2: Sensory evaluation of salted Mugil Cephalous using taste panel

\begin{tabular}{lccccccc}
\hline Parameters & 0 week & Month 1 & Month 2 & Month 3 & Month 4 & Month 5 & Month 6 \\
\hline Odour & $9 \pm 0.362$ & $8.4 \pm 0.368$ & $8 \pm 0.368$ & $6.7 \pm 0.10$ & $6 \pm 0.10$ & $5.5 \pm 0.10$ & $4 \pm 0.10$ \\
\hline & $9.1 \pm 0.10$ & $8 \pm 0.368$ & $7.1 \pm 0.368$ & $6.5 \pm 0.10$ & $5.5 \pm 0.10$ & $5.3 \pm 0.10$ & $3.9 \pm 0.10$ \\
Taste & $9.4 \pm 0.368$ & $8.6 \pm 0.368$ & $8.2 \pm 0.368$ & $7.1 \pm 0.368$ & $6.3 \pm 0.10$ & $6 \pm 0.10$ & $5.5 \pm 0.10$ \\
\hline Colour & & & & & & & \\
\hline Texture & $8.8 \pm 0.10$ & $7.1 \pm 0.10$ & $6.9 \pm 0.100$ & $6.4 \pm 0.368$ & $5.7 \pm 0.10$ & $5.2 \pm 0.10$ & $4.1 \pm 0.10$ \\
\hline $\begin{array}{l}\text { General } \\
\text { Appearance }\end{array}$ & $9.2 \pm 0.368$ & $8.5 \pm 0.368$ & $7.4 \pm 0.368$ & $6.1 \pm 0.10$ & $5.3 \pm 0.10$ & $5 \pm 0.10$ & $4.4 \pm 0.10$ \\
\hline
\end{tabular}

Table 3: Change in chemical composition of salted Mugil Cephalous during storage at room temperature $(\mathrm{g} / 100 \mathrm{~g})$

\begin{tabular}{cccccccc}
\hline Parameters & 0 week & Month 1 & Month 2 & Month 3 & Month 4 & Month 5 & Month 6 \\
\hline Moisture & $56.43 \pm 1.25$ & $49.84 \pm 1.05$ & $31.44 \pm 1.002$ & $18.73 \pm 0.10$ & $15.92 \pm 0.10$ & $13.02 \pm 0.10$ & $12.53 \pm 0.10$ \\
\hline $\begin{array}{c}\text { Sodium } \\
\text { Chloride }\end{array}$ & $11.7 \pm 0.13$ & $12.71 \pm 0.10$ & $13.59 \pm 0.106$ & $13.80 \pm 0.10$ & $14.10 \pm 0.103$ & $14.42 \pm 0.113$ & $14.57 \pm 0.11$ \\
\hline Protein & $16.20 \pm 0.39$ & $14.41 \pm 0.27$ & $13.92 \pm 0.101$ & $12.71 \pm 0.10$ & $11.43 \pm 0.103$ & $10.71 \pm 1.06$ & $9.88 \pm 1.10$ \\
\hline Lipid & $14.20 \pm 0.14$ & $14 \pm 0.10$ & $12 \pm 0.100$ & $11.83 \pm 0.113$ & $11.712 \pm 0.104$ & $11.512 \pm 0.103$ & $11.41 \pm 0.10$ \\
\hline Fiber & $1.23 \pm 0.103$ & $1.12 \pm 0.101$ & $1.02 \pm 0.11$ & $0.925 \pm 0.112$ & $0.832 \pm 0.108$ & $0.523 \pm 0.716$ & $0.340 \pm 0.10$ \\
\hline pH & 6.6 & 6.5 & 6.2 & 6.1 & 5.9 & 5.6 & 5.5 \\
\hline
\end{tabular}

Table 4: Changes in microbiological quality of salted Mugil Cephalous during storage at room temperature

\begin{tabular}{|c|c|c|c|c|c|c|c|}
\hline $\begin{array}{l}\text { Microbial counts } \\
\quad(\mathrm{cfu} / \mathrm{g})\end{array}$ & 0 week & Month 1 & Month 2 & Month 3 & Month 4 & Month 5 & Month 6 \\
\hline $\begin{array}{l}\text { Aerobic Plate } \\
\text { Count (APC) }\end{array}$ & $\begin{array}{c}6.5 \times 10^{3} \\
\pm 1.62 \times 10^{3}\end{array}$ & $\begin{array}{c}4.5 \times 10^{3} \\
\pm 1.41 \times 10^{2}\end{array}$ & $\begin{array}{c}2 \mathrm{X} 10^{3} \\
\pm 1.01 \times 10^{2}\end{array}$ & $\begin{array}{c}1.5 \times 10^{3} \\
\pm 10^{2}\end{array}$ & $<10$ & $<10$ & $<10$ \\
\hline Staph, aureus & $\begin{array}{c}2.5 \times 10^{2} \\
\pm 1.01 \times 10^{2}\end{array}$ & $\begin{array}{c}1.5 \times 10^{2} \\
\pm 1.13 \times 10\end{array}$ & $<10$ & $<10$ & $<10$ & $<10$ & $<10$ \\
\hline Yeast-molds & $<10$ & $<10$ & $<10$ & $<10$ & $<10$ & $<10$ & $<10$ \\
\hline Anaerobic Count & $<10$ & $<10$ & $<10$ & $<10$ & $<10$ & $<10$ & $<10$ \\
\hline
\end{tabular}




\section{DISCUSSION}

Currently, the moisture contents have recorded high value $63.23 \pm 1.35 \%$. The ash content was $2.4 \pm 0.19 \%$ while protein and lipid contents were $18.40 \pm 0.59 \%$ and $14.63 \pm 0.34 \%$ respectively. The fiber content was $1.34 \pm 0.12 \%$. These results agreed with those obtained by Mohamed et al. (2009).

Significant differences $(\mathrm{p}<0.05)$ in the sensory evaluation during storage period based on the panel's score In the present experiment, scores are the average of 20 panel taste sheets. It could be noticed that salted samples at 0 (week) has received higher scores followed by 1 month. Samples has received lowest scores at 3 months and 6 months the product was rejected. This wide range indicated the diversity in the final quality and can be largely attributed to the effect of various conditions upon the salting agents and activities. It is seen that the main factor affecting the quality is time of storage.

The moisture content changes were determined to be decreased progressively during the six months storage period. The moisture contents of salted samples were determined as $56.43 \pm 1.25 \%$ and $12.53 \pm 0.100$ at 0 week and 6 months respectively. The reduction in moisture contents during storage can be attributed to protein denaturation and consequent loss of waterholding capacity of examined fish samples. Dry salting produced considerable loss of constituent water due to heavy uptake of salt Martinez and Gomez (2006). The findings of present study are similar to the findings of Egbal et al. (2010). Changes of ash content of salted mugilcephalous samples were least $11.70 \pm 0.13 \%$ at 0 week, highest $14.57 \pm 0.113 \%$ at six months (Table 2). The relatively high ash content observed in salted samples can be attributed to the salt penetration into fish flesh during the curing process. The findings of present study nearly similarly to Farid et al. (2014).

The protein content of samples was determined least $9.88 \pm 1.06 \%$ at 6 months and highest $16.20 \pm 0.39 \%$ at 0 week as recorded It is evident that the protein content of processed fish has decreased after the course of salting, loss of protein during processing is extremely variable. In our results the losses of protein during storage period was averaged to $6.32 \%$. Salting of fish was usually accompanied by protein losses, as water is drawn out, some protein is dissolved into the brine (Clucas, 1981). Generally, the quantity of protein loss depends on the exact nature and duration of the salting.

Process and the conditions of fish when salted (Eltom, 1989). The lipid contents changes were determined to be at least $11.410 \pm 0.101 \%$ at the end of experiment period, and highest $14.20 \pm 0.14 \%$. It was clear from the present results that lipid content was decreased. Also fat might be decreased due to oxidative deterioration, thereby affecting lipid extraction (Farid et al., 2014). Similar results obtained by El-Sebahy and Metwalli (1988).

Changes in fiber content of salted mugil cephalous samples were found at least $0.340 \pm 0.104 \%$ and highest $1.23 \pm 0.103 \%$. The $\mathrm{pH}$ values of samples were determined least 5.5, highest 6.6.Similar results were reported by Bahri et al. (2006).

Concerning the APC in fresh fish used as raw material, ranged between $10^{2}$ and $10^{4} \mathrm{cfu} / \mathrm{g}$, the fish is more susceptible to microorganisms after catching. The number of bacterial counts may be possibly explained by contamination of fish during catching, handling, transportation and exposure to the surrounding environment (Gram, 1989). The bacterial flora on newly caught fish depends on the environment in which it was caught rather than on the fish species (Liston, 1980). The APC of salted samples were varied during storage time. The mean value at 0 week was $6.5 \times 10^{3} \pm 1.62 \times 10^{3} \mathrm{cfu} / \mathrm{g}$ (table $3)$. There was marked increase of APC in zero week, then after that the counts begin to decrease as salting proceeded. The early increase occurred while fish was wet and the provision of salt promoted the growth of halotolerant and halophilic bacteria in the fish. As the fish became drier there was decrease in water activity and this together with the accumulated salt in the flesh, resulted in suppression of bacterial growth. As chloride ions present in salt considered to be toxic for the microorganisms.

In this work $10^{4} \mathrm{cfu} / \mathrm{g}$ of the APC was used as the limit for the evaluation of microbial spoilage. When the aerobic plate count reach $10^{6} \mathrm{cfu} / \mathrm{g}$ the food product was assumed to be near spoilage (Ozogul et al., 2004).

In this study, the microbial growth was lower in salted samples and hasn't reach $10^{6} \mathrm{cfu} / \mathrm{g}$. however by the end of storage period growth was not detected. Staph. aureus count was determined in the samples. Small number of Staph. aureus in water products don't cause any health problems, however this microorganism can reach high level $\left(>5 \log _{10} \mathrm{cfu} / \mathrm{g}\right)$ in products prepared by hand under bad conditions leading to food poisoning (Varnam and Evans, 1991). In this study the values of Staph. aureus was begin with $2.5 \times 10^{2} \pm 1.01 \times 10^{2}$ in the zero week and disappear in the $3^{\text {rd }}$. month. No yeast or mold or anaerobic were detected in our fresh or salted samples. Also Clostridum Botulinum can't be detected in both fresh and salted samples. The quality of the product can be largely attributed to the effect of various conditions upon the salting agents and activities. It's seen that the main factor affecting the quality is time of storage. 


\section{CONCLUSION}

From the result of the present study, the sensory evaluation proximate analysis and $\mathrm{pH}$ value showed that dry salted product have greater nutritive value in terms of percentages crude protein and experimentally it has been proved that this product has longer shelf life and has found better way for preservation at laboratory condition.

\section{REFERENCE}

Afolbi, O.A.; Omosole, A.A. and Olusegun, L.O. (1984): Quality Changes of Nigerian traditionally processed fresh water fish species. I. Nutritive and organoleptic changes. J. Food Technol., 19: 333-340.

APHA (The American Public Health Association) (2001): Compendium of Methods for Microbiological Examination of Food, Washington, D.C.

Association of Official Analytical Chemists "AOAC", (2000): Official methods of analysis. $13^{\text {th }}$. Ed., w. Horwitz. W., (Editor), Academic press, Washington, D.C., USA.

Bahri, P.; Ayse, G.I.; Gulsum, O. and Irfan, I. (2006): Microbiological and chemical qualities of salted grey mullet. Int. J. Sci. Technol., 2: 9198.

Bligh, E.G.; and Dyer, W.J. (1959): A rapid method of total lipid extraction and purification. Canadian Journal of Biochemistry and Physiology, 37, 911-917.

Campton, R. (1981): In Campton's Encyclopedia, Publisher University of Chicago VSA.5: 601.

Clucas, I.J. (1981): Fish handling, preservation and processing in the tropics. Part I. Report of the tropical products institute. G144, VIII-144.

Egbal O. Ahmed; Mohammed E. Ali and Ali A. Hamed (2010): Quality Changes of Salted Kass (Hydrocynus forskalii) During Storage at Ambient Temperature $(37 \pm 1 \circ \mathrm{oC})$. Pakistan Journal of Nutrition 9 (9): 877-881.

El-Sebahy, L.A. and Metwally, M.S. (1988): Changes in some chemical characteristics and lipid composition of salted fermented Bouri fish muscle (Mugil Cephalous). Food Chemistry 31: 41-50.

Eltom, A.M. (1989): Microbiology and Biochemistry of Fessiekh fermentation. M.Sc. thesis (Agric.) University of Khartoum, Sudan.

Eyre, J.W.H. (EDIN.) (2009): The project Gutenberge Book of Elements of Bacteriology Technique. A laboratory Guide for Medical, Dental and Technical Students. Second Edition Rewritten and Enlarged eBook \#27713 ISO-8859-1.

Farid, F.B.; Latifa, G.A.; Nahid, M.N. and Begum, M. (2014): Comparison of the changes in phisicochemical characteristics of dry salted snake head shoal (Channa Striatus Bloch, 1801) and
Taki (Channa Punctatus Bloch, 1793) at room temperature $\left(27^{\circ} \mathrm{C}-31^{\circ} \mathrm{C}\right)$ Res. J. animal veterinary and fishery sci. 2 (9), 18-23.

Food and Drug Administration, (2001): Processing parameters Needed to Control Pathogens in Cold Smoked Fish, FDA Publication, U.S. Washington, District of Columbia, USA.P:979.

Ghay, A.E.; Dave, D.; Budge, S. and Brooks, M.S. (2010): Fish spoilage mechanism and preservation techniques review. American Journal of Applied Sci.7 (7): 859-877.

Gram, L. (1989): Identification, Characterization and Inhibition of bacteria isolated from Tilapia fish. Ph.D. thesis, Royal Veterinary and Agriculture University, Lyngby, Denmark.

Huss, H.H. (2003): Assessment and management of seafood safety and quality. Food Agriculture Organization, Publications, P: 103-109.

ICMSF, (1996): Microorganisms in food: 111 Microbial Specifications of Food Pathogens. (2). Chapman and Hall. London, New York.

ISO 21527, (2008): Microbiology of food and animal feeding stuffs -- Horizontal method for the enumeration of yeasts and moulds.

Liston, G. (1980): Microbiology in fisheries science in Connell, J.J (Ed.) Advances in fisheries science and technology, Fishing News Books Ltd, Farnham, England, p.p:138-157.

Ludorf, M. and Meyer, W. (1973): Fische und fischerzeugnisse. Hamburg-Berlin: Paul PareyVerlag.

Martinez- Alvarez, O. and Gomez-Guillen, M.C. (2006): Effect of brine salting at different pH's on the functional properties of cod muscle proteins after subsequent dry salting. Food Chem., 94:123-129.

Mohamed, R.; Livia, S.S.; Hassan, S.; Soher El-seedy and Ahmed, A. (2009): Changes in free amino acids and biogenic amines of Egyptian saltedfermented fish (Feseekh) during ripening and storage. Food Chemistry, 115(2): 635-638.

Ozogul, F.; Polat, A. and Ozogul, X. (2004): The effects of modified atmosphere packaging and vacuum packaging on chemical, sensory and microbiological changes of sardines (Sardina Pilchardus). J. Food Chem. 85:49-57.

Pifco, (1974): Dehydrated culture media reagents and procedures. Pup pifco laboratory incorporated Detroit, I., Michigan, 48:201, U.H.A.

Shena, S.S. and Sanjeev, S. (2007): Prevalence of enterotoxigenic Staphylococcus aureus in fishery products and fish processing factory workers, Food Control, 18 (12) 1565-1568.

Turan, H.; Sönmez, G.; Çelik, M.Y. and Yalçin, M. (2007): Effects of different salting process on the storage quality of Mediterranean Muscle (Mytilus Galloprovincialis L. 1819). Journal of Muscle Foods, 18: 380-390. 
Varnam, A.H. and Evans, M.G. (1991): Foodborne pathogens. The Netherlands. Wolf Science Book.

Yohanna, J.; Fulani, A.U.; Aka and Ama, W. (2011): Prospects for the adaptable technological innovation in fresh fish processing and storage in rural area of Domal L, G.A. of Nasarwaastate. Journal of Agricultural Science 3 (3): 282-286.

\section{تغيرات الجودة لأسماك البورى المملح أثناء تخزينها فى درجة حرارة الغرفة

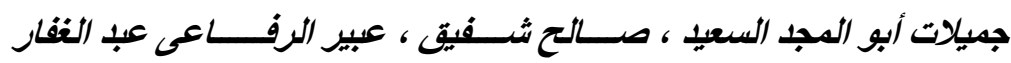

Email: saleh-shafik@yahoo.com

Assiut University web-site: www.aun.edu.eg

أجريت هذه الدراسة لمعرفة تأثير إضافة الملح بنسبة هب \% \% والحفظ فى درجة حرارة الغرفة على القيمة الغذائية والحالة

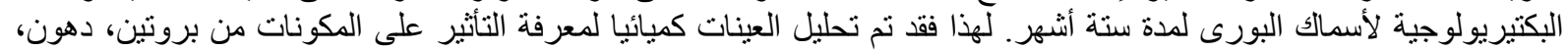

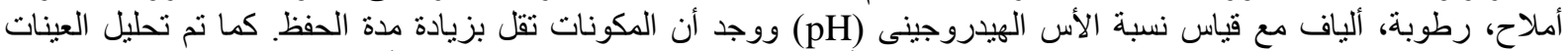

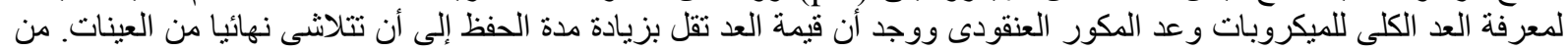



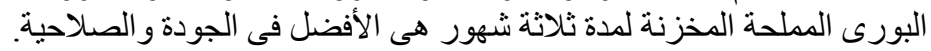

